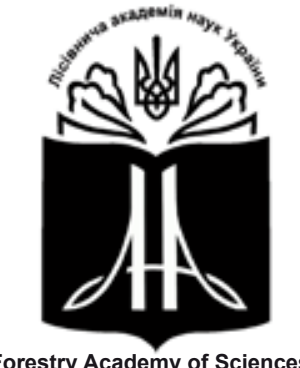
of Ukraine

Наукові праці Лісівничої академії наук України

Proceedings of the Forestry Academy of Sciences of Ukraine

http://fasu.nltu.edu.ua

https://doi.org/10.15421/411830

Article received 2018.08.20

Article accepted 2018.10.25
ISSN 1991-606X print

ISSN 2616-5015 online

(a) $\triangle$ Correspondence author Stepan Stojko

stepan.stojko@gmail.com

Konovalets st., 97/14, Lviv, 79057, Ukraine

УДК $574 / 458+577.4 ; 577.486$

\title{
Екологія, ценотична гетерогенність формації бука лісового в Україні та збереження пралісових екосистем
}

\author{
С.М. Стойко ${ }^{1,2}$
}

В Україні у гумідному кліматі Карпат існують оптимальні екологічні умови для зростання букових лісів, а на Поділлі - на східноєвропейській межі ареалу в сухішому кліматі - вони поширені лише локально. Подано екологічну оиінку фізико-географічних регіонів Карпат, Розточчя, Опілля, Поділля, в яких поширені монодомінантні й мішані бучини та встановлено їхню фітоценотичну різноманітність. 3'ясовано роль антропогенних чинників, які є причиною зменшення їхньої площі. Подано перелік масивів природних бучин у Карпатах, внесених МАБ ЮНЕСКО до Списку об 'єктів світової природної спадщини. Обтрунтовано науково-природниче й екомодельне лісівниче значення букових та інших пралісових екосистем

Відзначено, щзо пралісові фітоценози мають модельне значення для обтрунтування системи вирощування лісів, близьких за иеенотичною структурою до природних екосистем та вибіркового лісокористування. Така система дає змогу усунути суперечності між екологічними вимогами щзодо збереження постійності лісів та економічними потребами використання лісових ресурсів.

Наголошено, шуо пралісові екосистеми відзначаються біологічним різноманіттям. 3 їх осередків можлива міграція аборигенних видів флори й фауни у трансформовані прилеглі ліси та луки, щчо сприятиме покращенню їх иченотичної стабільності. У пралісових фітоценозах нагромадилася багата інформація про спонтанний розвиток лісів, їх природну вікову й изенотичну структуру. Тому праліси мають винятково важливе значення для дослідження лісотвірного процесу та функиіонування екологічно стабільних екосистем.

У Карпатському біосферному заповіднику, в Начіональних природних парках «Зачарований край» та «Уэанський» представлена вся фітоиенотична різноманітність монодомінантних й полідомінантних букових лісів країн Західної Свропи. Вони мають важливе значення для обтрунтування екологічних засад відновлення бучин та ведення лісового господарства на природних засадах. Потрібно приділити належну увагу їх збереженню, дослідженню та впровадженню результатів у покращання екологічного стану лісів формації бучин.

Ключові слова: охорона природи; фітоценотична різноманітність; праліс; квази-праліс; клімаксова екосистема.

Вступ. Деревина бука в минулому не мала промислового значення й використовувалась здебільшого для опалення житлових будинків. Тому збереженню букових лісів не приділяли належної уваги. У гірській місцевості Карпат, де було мало придатних для землеробства земельних угідь, на родючих під буковими лісами буроземних грунтах вирощували картоплю, кукурудзу й інші сільськогосподарські культури, що було вигідно з економічних міркувань. 3 розвитком промисловості, для якої було потрібно багато деревини хвойних порід, букові ліси трансформували в монокультури ялини. Упродовж останніх двох століть в Карпатах площа букових лісів зменшилася на 272 тис. га, а ялино-

\footnotetext{
Стойко Степан Михайлович - професор, доктор біологічних наук, доктор honoris causa Зволенського технічного університету (Словаччина) та Львівського державного університету безпеки життєдіяльності (Україна), вул. Коновальця, 97, м. Львів, 79057, Україна. Тел.: +38-098-314-35-91. E-mail: stepan.stojko@gmail.com

2 Автор цієї наукової статті 14 березня 2018 року відсвяткував своє 98-річчя
} 
вих монокультур - збільшилася на 325 тис. га. Широкомасштабна трансформація у територіальній структурі природних лісів негативно позначилася на екологічному балансі довкілля та біологічному різноманітті природної флори. Рідкісними стали численні види фауни, трофічно залежні від букових лісів. Тому їхнє збереження сприятиме збереженню біорізноманітності.

Фізико-географічні регіони поширення формації бука лісового. Бук лісовий як мезофітний вид охоплює велику територію у країнах Західної та Центральної Європи, де проявляється вплив атлантичного клімату. Головні причини обмеженого поширення букових лісів - континентальність клімату, недостатня кількість опадів, низька температура в зимовий період. Коли, за даними кліматологів, у Карпатах в лютому 1928 р. температура знизилася в Закарпатті до $-42^{\circ} \mathrm{C}$, в багатьох місцях на стовбурах буків виникли морозобоїни, які стали причиною розвитку грибних захворювань і зниження якості деревини.

Територія України цікава для дослідження формації бучин, оскільки в помірному й гумідному кліматі Карпат існують оптимальні для букових лісів екологічні умови, а на Поділлі, в Хмельницькій області, проходить східноєвропейська межа ареалу бука лісового. Дослідженню букових лісів в Україні присвячені праці багатьох учених (Molotkov, 1962, Parpan, Stojko, \& Parpan, 2013, Parpan, 1994, Miklush, 2011, Cherniavsky, 2000). Вони мають важливе значення для оптимізації ведення лісового господарства в букових лісах та раціонального використання їхніх ресурсів. Результати досліджень формації бука в сусідній Словацькій республіці опубліковано в монографії професора Ш. Корпеля «Праліси Словаччини», перевиданій у Федеративній Республіці Німеччини (Korpel, 1989). Автор слушно констатував, що завдяки авторегуляційній здатності пралісові екосистеми краще можуть подолати стихійні й антропогенні зміни у природній структурі екосистем, ніж ліси культурного походження. Тому вони $є$ природними еталонами для ренатуралізації трансформованих деревостанів й формування екологічно стабільних лісів. У букових лісах Карпат упродовж останніх двох століть відбулися значні територіальні та ценотичні зміни, які позначилися й на збідненні їхньої біологічної різноманітності та екологічній стабільності. Однак дослідженню цих питань та збереженню природних лісів не приділено належної уваги.

В Україні букові ліси стали поширюватися у пізньому голоцені (чотири тис. років тому) в умовах сприятливого для них вологого клімату. Поступово відбувалася природна сукцесія дубових лісів з дубів звичайного й скельного в бучини, а в гірських районах - ялинових лісів у бучини. Так сформувався широкий пояс природних букових лісів, середня висота яких в Закарпатті сягає 1280 м н.р.м., а максимальну спостережено в Свидовецькому гірському масиві 1380 м н.р.м. Пояс суцільних ялинових лісів зберігся лише в холодному кліматі Чорногірського масиву, Мармароського Попа Івана та Горган.

У сучасний період можна виділити три фізикогеографічні регіони природного поширення бучин, які відрізняються їх ценотичним різноманіттям Карпати, Розточчя й Опілля, Поділля (табл. 1).

Таблиия 1

Екологічні умови поширення бучин у різних фізико-географічних регіонах

\begin{tabular}{|c|c|c|c|c|c|}
\hline \multirow{3}{*}{ Екологічні умови } & \multicolumn{5}{|c|}{ Регіони } \\
\hline & \multicolumn{2}{|c|}{ Карпати } & \multirow{2}{*}{$\begin{array}{l}\text { Розточчя } \\
\text { й Опілля }\end{array}$} & \multicolumn{2}{|c|}{ Поділля } \\
\hline & $\begin{array}{l}\text { південний } \\
\text { макросхил }\end{array}$ & $\begin{array}{c}\text { північний } \\
\text { макросхил }\end{array}$ & & західне & східне \\
\hline Характер поширення & суцільне & суцільне & диз’юнктивне & $\begin{array}{c}\text { острівні } \\
\text { локалітети }\end{array}$ & $\begin{array}{l}\text { східна межа } \\
\text { поширення }\end{array}$ \\
\hline Середня висота н.р.м., м & $400-1280(1380)$ & $600-1000$ & $300-350$ & $300-350$ & $300-350$ \\
\hline $\begin{array}{l}\text { Амплітуда температур } \\
\text { (I-VII місяці), }{ }^{\circ} \mathrm{C}\end{array}$ & $21.7-22.2$ & $21.3-22.4$ & 24.2 & 24.2 & 25 \\
\hline $\begin{array}{l}\text { Абсолютний річний } \\
\text { мінімум температури, }{ }^{\circ} \mathrm{C}\end{array}$ & -28 & -25 & -25 & -32 & -32.2 \\
\hline $\begin{array}{l}\text { Річна кількість } \\
\text { опадів, мм }\end{array}$ & 1205 & 1407 & $881-660$ & 610 & 540 \\
\hline $\begin{array}{l}\text { Характер лісових } \\
\text { екосистем }\end{array}$ & $\begin{array}{c}\text { монодомінантні, } \\
\text { полідомінатні }\end{array}$ & $\begin{array}{l}\text { монодомінантні, } \\
\text { полідомінантні }\end{array}$ & полідомінантні & полідомінантні & полідомінантні \\
\hline
\end{tabular}

Бук лісовий - тіньовитривала деревна порода, й тому в оптимальних екологічних умовах Карпат $\epsilon$ потужним едифікатором. Його підріст може існувати під наметом лісу 50-60 років, а після повного освітлення може продовжувати нормально розвиватись. Тому складно встановити вік дерев за ознаками їхніх діаметрів. Залежно від екологічних умов, бук формує в згаданих екорегіонах як монодомінантні, так і полідомінантні (мішані) фітоценози. 
У Закарпатті на південному макросхилі вулканічної гряди в минулому суцільний висотний пояс утворювали дубово-букові ліси з дуба скельного (Querceto-petraeae - Fagetum). Починаючи 3 XVII ст., на теплих схилах почали культивувати сади й виноградники, тому на сьогодні залишилися тільки рештки цих природних лісів в Ужгородському, Свалявському, Виноградівському державних лісових господарствах. Монодомінантні бучини збереглися в Національних природних парках - Ужанському, Зачарований край, в УгольськоШироколужанському масиві Карпатського біосферного заповідника. На вапнякових схилах Великої Угольки локально поширені угрупування рідкісних тисових (Taxoso-Fagetum), липових (Tilieto platyphylli - Fagetum), грабових (Carpineto-Fagetum) бучин. Локалітети тисових бучин виявлено також на карбонатних породах на лівобережжі Білого потоку в Діловецькому заповідному лісництві, у Княж-дворі на Івано-Франківщині, в околицях Чернівців на Буковині. Для їх збереження створено лісові заказники.

У Бескидах, вище від межі букових лісів, раніше був сформований висотний пояс ялицево-букових та буково-ялицевих лісів (Abieto-Fagetum, FagetoAbietum). Унаслідок вирубування ялиці ці мішані ліси поступово трансформувалися у монодомінантні бучини. Полідомінантні ялицево-букові ліси трапляються фрагментарно в Ужанському НПП.

За характером кліматичних умов північний мегасхил Карпат, який знаходиться під впливом клімату Балтійського моря та руської платформи, відрізняється від південного, що проявляється й на висотній поясності лісових формацій. Певне значення має й висота над рівнем моря Передкарпаття, яка коливається в межах 300-350 м н.р.м. Тому на ІваноФранківщині немає поясу буково-дубових лісів 3 дуба скельного. Його фрагменти збереглися в теплішому кліматі на Буковині - в околицях Чернівців.

На Львівщині в Національному природному парку «Сколівські Бескиди» поширені природні букові ліси та фрагменти ялицевих бучин, які мають значення для збереження популяцій зубра. На Розточчі й Опіллі локально поширені полідомінантні бучини. На піщаних грунтах Розточчя збереглася рідкісна для України субформація сосново-букових лісів (Pineto-Fagetum sylvaticae). Бук лісовий, завдяки багатому на зольні речовини відпаду, має меліоративне значення. Тому соснові субучини відзначаються високою продуктивністю. Зростання бука на піщаних грунтах Розточчя свідчить про можливість його культивування в соснових лісах Полісся як меліоративної породи.

Бук лісовий - монтанна деревна порода. На підвищених формах рельєфу Опілля збереглися фрагменти грабово-букових (Carpineto-Fagetum) та грабово-дубово-букових (Carpineto-Querceto roboris-Fagetum) лісів.

3 фітогеографічного й екологічного погляду, цікавим $є$ локалітет букових лісів у Хмельницькій області (49¹0' 41" північної широти й 261' 51 "схід- ної довжини). Для збереження популяцій бука та рідкісних рослин, занесених до Червоної книги, в 1977 р. у Сатанівському лісництві Ярмолинецького держлісгоспу було створено на площі 250 га ботанічний заказник «Сатанівська дача». Згідно $з$ Постановою Ради Міністрів Української РСР від 7 січня 1985 р., на його базі було створено на площі 1778 га Сатанівський лісовий заказник загальнодержавного значення. У заказнику поширені природні грабово-букові (Carpineto-Fagetum) та дубово-букові (Querceto roboris - Fagetum) деревостани віком 100-150 років (рис. 1).

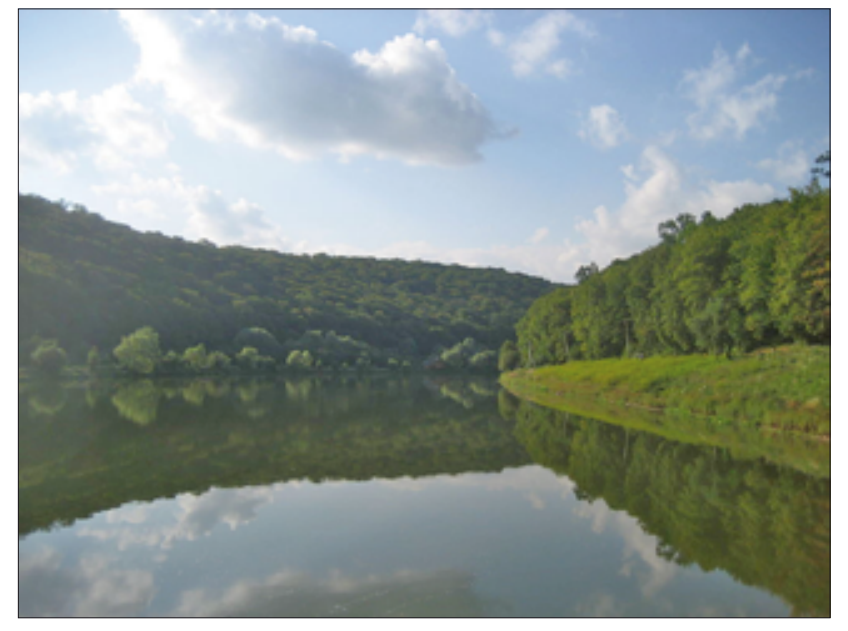

Рис. 1. Загальний вигляд Сатанівського заказника природних букових лісів у Сатанівському лісництві

Хмельницької області (фото із архіву лісництва)

У географічно ізольованому заказнику добре збереглася подільська популяція бука лісового. Вона цікава $з$ погляду дослідження еколого-біологічних властивостей бука на східноєвропейській межі ареалу, а також як лісонасінний об'єкт для створення культур бука на прилеглих територіях.

В Україні у згаданих вище фізико-географічних регіонах, залежно від грунтово-кліматичних умов, сформувалися дві ценотичні категорії лісів - монодомінатні та полідомінантні (мішані) бучини. Серед монодомінантних бучин на особливу уваги заслуговують «клімаксові екосистеми». Поняття «клімаксу» рослинних формацій обгрунтував американський біолог Clements (1936) й воно широко вживається в англомовній фітоценотичній літературі. Клімакс заключна, стабільна стадія у тривалому процесі філоценогенезу рослинних угрупувань. Найважливіша властивість клімаксових екосистем - стабільне існування й функціонування без небезпеки сукцесії 3 боку прилеглих до них інших екосистем.

В Українських Карпатах до клімаксових бучин можна віднести монодомінантні екосистеми, сформовані в оптимальних для бука кліматичних й едафічних умовах у межах висот 600-900 м н.р.м. на теренах Угольсько-Широколужанського масиву Карпатського біосферного заповідника та Національних природних парків - «Ужанський» і «Зачарований край». У клімаксових бучинах переважачою є бучина зубницева (Dentario-Fagetum), яка 
відзначається високою повнотою деревостану, грубою, слабо розкладеною підстилкою з характерних неморальних видів (рис. 2).

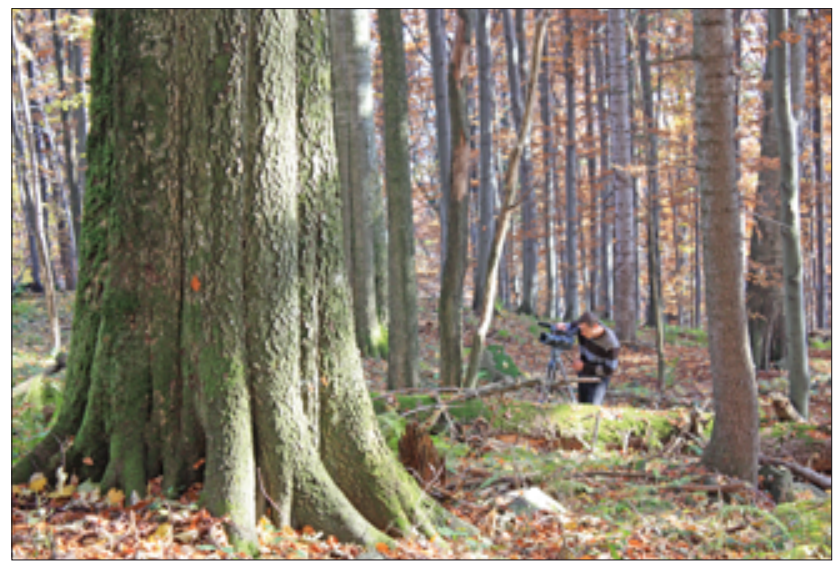

Рис. 2. Клімаксова бучина (Dentario-Fagetum) в Ужанському національному природному парку. На передньому плані сенільний стовбур бука (фото автора)

Клімаксові бучини - монодомінантні, високоповнотні, різновікові, стійкі проти сукцесії. При відмиранні сенільних стовбурів їх екологічні ніші займають стовбури молодші, в яких продовжується приріст фітомаси. Тому в клімаксових екосистемах зберігається стабільний запас деревини. Дослідженню ценотичної структури клімаксових бучин в Широколужанському заповідному масиві присвячено низку наукових публікацій (Zlatnik, 1938, Stoyko et al. 1982, Stoyko, 1992, Stoyko, 1998, Shparyk, 2011, Shparik, Berkela, \& Pavlyuk, 2016). Клімаксові бучини мають екомодельне значення для обгрунтування екологічних засад сталого лісового господарства в монодомінантних бучинах.

У Карпатах, у формації бучин своєрідною ценотичною й морфологічною категорією є букове криволісся, яке трапляється на висотній межі їх поширення (рис. 3). Воно утворюється за низьких температур, а отже, при скороченому вегетаційному періоді. Певне значення має також анемо-орографічний чинник - вплив холодних вітрів на верхній межі лісу. Унаслідок тривалого випасу худоби криволісся поступово зникало. Тепер воно збереглося лише на вершині гори Кременець в Ужанському НПП, на верхній межі бучин у Національному природному парку «Зачарований край», в субальпійському поясі Богданського лісництва в Чорногорі.

Характерні компоненти криволісся - явір (Acer pseudoplatanus), горобина (Sorbus aucuparia), черемха (Prunus padus). У трав'яному вкритті переважають ожика гайова (Luzula nemorosa), плавун булавовидний (Lycopodium clavatum) й інші мезотрофтні види. Криволісся бука, сосни гірської, зеленої вільхи, ялівцю сибірського мають захисне значення в лавинонебезпечних місцевостях.

Ліси, порівняно з іншими рослинними формаціями, відзначаються довготривалим періодом існування. У букових лісах, а також в інших лісових формаціях, важливе екологічне значення мають пралісові екосистеми. Упродовж філоценогенезу в них виробилась природна здатність до самовідновлення, саморегуляції (регуляції ценотичної структури), самозахисту від біологічних шкідників. Тому праліси функціонують як екологічно стабільні екосистеми. На відміну від культурних фітоценозів, у пралісах не розриваються функціональні зв'язки між автотрофним i гетеротрофним компонентами й педосферою. Характерною їхньою ознакою є наявність послідовних вікових ценотичних груп ювенільної, віргінільної, іматурної, сенільної, груnu розпаду фітоценозу. Локальні екологічні ніші в місцях розпаду пралісу займають ювенільні (підріст), віргінільні (жердняки) та особини інших ярусів. Тому пралісові екосистеми не старіють, у них залишається постійний запас деревини.

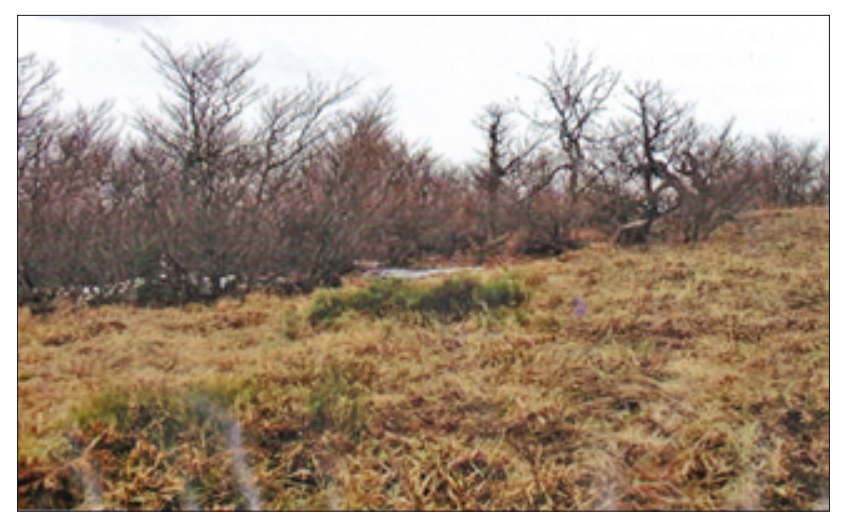

Рис. 3. Криволісся бука лісового (Fagetum vacciniosum myrtilli humile) віком понад 120 років, на висоті 1200 м н.р.м. на горі Кременець в Ужанському НПП (фото автора)

Беручи до уваги характерні ценотичні ознаки пралісу, можна дати таке його визначення: праліс - це сформована упродовж філоценогенезу екосистема, в якій представлені усі вікові групи - від ювенільної до групи розпаду иенозу, взаємозв'язки між автотрофним і гетеротрофним блоками та педосферою, й тому він функиіонує як саморегульована екосистема.

Букові ліси Карпат, на відміну від ялинових, розташовані в густозаселеній місцевості, в якій розгалужена мережа лісових доріг, рекреація, розвинена туристична галузь впливають на їхній природний стан. Тому, залежно від такого стану, варто розглядати дві категорії пралісових екосистем - справжні праліси та умовні праліси (квазипраліси). На підставі порівняльних досліджень природного стану гірських лісів у Карпатах подано найважливіші ценотичні критерії їх визначення в натурі (табл. 2).

Оцінювання природного стану пралісів потрібно здійснювати за наведеними у таблиці критеріями та застосовувати заходи щодо усунення негативного антропогенного впливу на них.

Антропогенні причини зменшення площі букових лісів. Площа букових лісів в Україні й інших країнах Європи зменшувалася унаслідок різного виду антропогенного впливу. У середньовіччі, 
після завезення з Південної Америки на наш континент картоплі й соняшнику, ці важливі для населення сільськогосподарські культури після рубання та викорчовування букових лісів стали вирощувати на родючих буроземних грунтах, що з економічних міркувань було вигідним. У багатьох місцях, в яких у болотній руді були поклади заліза, для його добування використовували висококалорійну деревину бука. На Закарпатті в гірському селі Тур'я-Ремета у 1872-1873 рр. щороку спалювали до 15 тис. м $^{3}$ букової деревини (Delehan, 2005).

Деревину бука в другій половині XVIII ст. використовували також для виготовлення поташу, який експортували на закордонні ринки. За даними історика I. Шульги, на Свалявщині у 1896 р. було вироблено 7496 центнерів поташу-сирцю. У лісах Ужгородської лісової дирекції упродовж 1856-1886 pp. для вироблення поташу щороку використовували $50 \mathrm{~m}^{3}$ букової деревини.

Німецько-швейцарська лісопромислова компанія на початку XX ст. збудувала в Перечині та Великому Бичкові потужні лісохімічні заводи, в яких щороку переробляли на різні хімічні продукти 6070 тис. м $^{3}$ деревини бука. Оскільки бук не мав промислового значення, на його лісосіках створювали культури ялини як швидкорослої деревної породи.

Таблиия 2

\section{Еколого-ценотичні критерії визначення в натурі пралісових екоситем}

\begin{tabular}{|c|c|c|}
\hline \multirow{2}{*}{ Еколого-ценотичний критерій } & \multicolumn{2}{|c|}{ Категорії пралісів } \\
\hline & пралісова екосистема & квази-пралісова екосистема \\
\hline $\begin{array}{l}\text { Наявність вікових категорій (ювенільної, } \\
\text { віргінільної, іматурної, сенільної, фази розпаду) }\end{array}$ & забезпечена & забезпечена \\
\hline $\begin{array}{l}\text { Закономірний розподіл деревостану за ступенями } \\
\text { товщини (за діаметром) }\end{array}$ & забезпечений & забезпечений \\
\hline Природний стан педосфери та гумусного горизонту & забезпечений & можливі локальні зміни \\
\hline Природне відмирання та гниття стовбурів & забезпечені & можливе локальне порушення \\
\hline $\begin{array}{l}\text { Відповідність природним умовам середовища } \\
\text { аборигенної фауни }\end{array}$ & забезпечена & забезпечена \\
\hline $\begin{array}{l}\text { Здатність відновлення природного стану пралісу } \\
\text { в разі його порушення }\end{array}$ & - & 1-2 десятиліття \\
\hline
\end{tabular}

3 початку XIX ст. у країнах Свропи почала розвиватись паперова промисловість, для якої було потрібно багато хвойної деревини. Тому на місці зрубаних букових лісів створювали монокультури хвойних порід. За дослідженнями Golubets (1978), упродовж останніх двох століть площа букових лісів в Карпатах зменшилася на 272 тис. га, або на $40 \%$. Адекватно зросла площа ялинових лісів - від 126 до 325 тис. га. Як виявилось згодом, за межами природного ареалу ялинники були ценотично нестабільними й почали всихати. Така масштабна зміна в лісових формаціях негативно позначилася на збідненні видового складу трофічно пов'язаних 3 ними видів хребетних тварин, був порушений гідрологічний режим гірських річок, що стало причиною частішого виникнення небезпечних повеней.

Враховуючи такі антропогенні зміни в гірських лісах, далекоглядні лісівники стали приділяти увагу збереженню природних бучин. В Австро-Угорській імперії угорські лісівники створили в 1913 р. у верхів'ї басейну Ужа два букові резервати. Чеський професор Zlatnik (1938) обгрунтував потребу розширення їхньої площі й провів у 1937 р. дослідження ценотичної структури пралісових екосистем. На Львівщині у 20-х роках XX ст. природолюб граф Дзєдушицький у своєму маєтку в околицях с. Пеняки створив буковий резерват.

Масштабна трансформація букових лісів відбувалася і в інших країнах Західної Європи. На Лі- совому конгресі ІЮФРО в 1976 р. було створено спеціальну науково-дослідну групу вчених «Праліс» (Urwald), завдання якої полягало у виявленні та збереженні цінних у науково-природничому аспекті природних букових й інших лісів. У 1988 р. у Словаччині у Зволенському інституті лісівництва та переробки деревини ІЮФРО провела міжнародний симпозіум з проблем збереження букових лісів (3 IUFRO Buchensymposium). Його учасники констатували критичний екологічний стан формації бучин на континенті та потребу їхнього збереження. У 1992 р. в Іспанії у місті Памплона було проведено міжнародний конгрес щодо бука (International Congress on beech). У прийнятих на ньому рішеннях було констатовано, що сучасні кліматичні умови сприятливі для збільшення площі букових лісів, але вона обмежується внаслідок різних антропогенних дій. Відзначено, що букові ліси мають вагоме потенціальне значення як в економічній, так і в соціальній (рекреаційній) сферах. Тому потрібно приділити належну увагу дослідженню природного середовища в існуючих та потенційних районах зростання букових лісів. Рекомендовано проводити дослідження генетичних та фенотипічних варіантів бука з метою його генетичного покращення та створення генетичних банків плодів «in situ» та «ex situ». Потрібно продовжувати дослідження впливу антропогенних чинників на екосистеми букових лісів та обгрунтувати заходи 
їхнього відновлення. Ці рекомендації конгресу актуальні й для України.

Екологічні заходи збереження букових лісів. 3 огляду на значні територіальні та ценотичні зміни у бучинах Карпат, науковці стали приділяти належну увагу їхньому збереженню (Stoyko, 1988, Stoyko, 1992, Cherniavsky, 2000, Shparyk, 2011, Parpan et al., 2013, Krynyckyy et al., 2014). На підставі вивчення різними дослідниками поширення букових лісів та їх природного стану на теренах Українських й Словацьких Карпат, науковці Карпатського біосферного заповідника спільно із словацькими вченими провели інвентаризацію старовікових бучин, визначили навколо них буферну зону й подали до комісії МАБ ЮНЕСКО номінацію для їх внесення до Списку світової природної спадщини (Hamor, 2011). До номінації внесено масиви букових лісів, які охороняються у природно-заповідному фонді (табл. 3).

Комітет МАБ ЮНЕСКО на 31-й сесії 2007 р. у Новій Зеландії ухвалив рішення про внесення Українсько-Словацької номінації «Букові праліси Карпат» до Списку об'єктів світової природної спадщини. У цьому Списку є 197 цінних у біогеографічному аспекті природних об'єктів та 31 об'єкт, цінний у культурному й природничому аспектах. У ньому зосереджені такі унікальні природні об'єкти, як
Ніагарський водоспад, Галапагоські острови, озеро Байкал, Сллоустонський національний парк та інші.

У країнах Західної Європи збереглися на обмеженій площі старовікові букові ліси. Лісівники Федеративної Республіки Німеччини, Австрії, Італії, Іспанії й інших країн подали до МАБ ЮНЕСКО номінацію внесення їх до Списку природних об'єктів світового значення. Комітет МАБ на черговому засіданні 7 липня 2017 р. у Кракові схвалив номінацію «Давні первинні ліси Карпат та інших регіонів Європи». Вона включає ядрову зону букових лісів площею 91 232,81 га та буферну зону - 254 769,75 га, разом - 346002,56 га.

У згаданій номінації Україна посідає провідне місце за площею букових пралісів. У Карпатському біосферному заповіднику, в Національних природних парках «Зачарований край» та «Ужанський» представлена вся фітоценотична різноманітність монодомінантних й полідомінантних букових лісів країн Західної Європи. Вони мають важливе значення для обгрунтування екологічних засад відновлення бучин та ведення лісового господарства на природних засадах. Потрібно приділити належну увагу їх збереженню, дослідженню та впровадженню його результатів у покращання екологічного стану лісів формації бучин.

Таблиия 3

Розташування букових пралісів українсько-словацької номінації «Букові праліси Карпат»

\begin{tabular}{|c|c|c|c|c|}
\hline № 3/П & Розташування букових пралісів & Гірський масив та його вершини & Заповідна зона, га & Буферна зона, га \\
\hline 1 & $\begin{array}{l}\text { Карпатський біосферний } \\
\text { заповідник }\end{array}$ & Чорногірський & 2476,8 & 12925,0 \\
\hline 2 & $-/ /-$ & Угольсько-Широколужанський & 11860,0 & 3301,0 \\
\hline 3 & $-/ /-$ & Свидовецький & 3030,5 & 5639,5 \\
\hline 4 & $-/ /-$ & Мармароський & 2243,6 & 6230,4 \\
\hline 5 & $-/ /-$ & Кузій-Трибушанський & 1369,6 & 3164,4 \\
\hline 6 & $\begin{array}{l}\text { Ужанський національний } \\
\text { природний парк }\end{array}$ & Стужиця, Ужок & 2532,0 & 3615,0 \\
\hline 7 & $\begin{array}{l}\text { Словацька республіка } \\
\text { Національний парк «Полонини» }\end{array}$ & Стужиця, Буковські Верхи & 2950,0 & 11300,0 \\
\hline 8 & $\begin{array}{l}\text { Природоохоронна область } \\
\text { «Пряшівщина» }\end{array}$ & Рожок & 67,1 & 41,4 \\
\hline 9 & $-/ /-$ & Вигорлат & 2578,0 & 2413,0 \\
\hline \multirow[t]{2}{*}{10} & $-/ /-$ & Гавешова & 171,3 & 63,99 \\
\hline & Разом & & 29278,9 & 48692,7 \\
\hline
\end{tabular}

Багатофункціональне значення букових та інших пралісів. Лісові формації - домінантний тип рослинності на нашій планеті. Вони мали, мають й матимуть важливе значення в різних сферах життедіяльності суспільства - економічній, екологічній, етнокультурній, соціальній. Сучасний техногенний вік відзначається активним процесом денатуралізації природних ландшафтів. У збереженні їх екологічного балансу, а отже, й нашого життєвого середовища, вагома роль належить природним лісам, які мають багатогранне науково-природниче, екологічне, соціальне значення.
Логістичне значення. Упродовж філоценогенезу у природних лісових екосистемах нагромадилася важлива інформація про складні екологічні взаємозв'язки між фітоценозом, зооценозом, педосферою. Тому вони є своєрідною природною лабораторією для фітоценології, ботаніки, зоології, педології й інших природничих наук, які вивчають ці взаємозв'язки.

Значення для збереження раритетного генофонду рослинного й тваринного світу. У природних лісових екосистемах зберігаються дикі родичі плодових дерев і чагарників, які мають значення 
для використання їхнього генофонду для покращання культурних сортів. Таке ж їхнє вагоме значення для збереження популяцій раритетної аборигенної фауни.

Значення для екологічного моніторингу впливу глобального потепління на динаміку лісових екосистем. У Карпатах для такої мети придатні природні букові та яворово-букові праліси на верхній межі лісу в Ужанському НПП на полонинах Кременець (1221 м н.р.м.), Кінчик Буковський (1251 м н.р.м). За динамікою ялинових лісів та криволіссям гірської сосни й вільхи зеленої доцільно організувати моніторинг на Попі Івані Мармароському (1927 м н.p.м.) та Попі Івані Чорногірському (2021 м н.р.м.).

Еталонне значення для лісознавства та лісівниuтвва. Пралісові фітоценози мають модельне значення для обгрунтування системи вирощування лісів, близьких за ценотичною структурою до природних екосистем та вибіркового лісокористування. Така система дає змогу усунути суперечності між екологічними вимогами щодо збереження постійності лісів та економічними потребами використання лісових ресурсів.

Фітоісторичне значення. На теренах УгольськоШироколужанського заповідного масиву Карпатсього біосферного заповідника та Ужанського НПП, серед зонально поширених клімаксових бучин, збереглися $з$ раннього й пізнього голоцену реліктові ялинові, дубові з дуба скельного, березові фітоценози, які мають значення для дослідження розвитку рослинності в післяльодовиковому періоді.

Біодисперсне значення. Пралісові екосистеми відзначаються біологічним різноманіттям. 3 їхніх осередків можлива міграція аборигенних видів флори й фауни у трансформовані прилеглі ліси та луки, що сприятиме покращенню їхньої ценотичної стабільності.

Екоосвітнє значення. У пралісових фітоценозах нагромадилася багата інформація про спонтанний розвиток лісів, їх природну вікову й ценотичну структуру. Тому вони мають значення для дослідження лісотвірного процесу та функціонування екологічно стабільних екосистем.

Ландшафтно-естетичне значення. У пралісах збереглися різноманіття, гармонія і краса споконвічної природи. Вони є цікавими об'єктами для задоволення духовних й емоціональних потреб людини. Непорушені лісові ландшафти мають також значення для живопису й інших галузей мистецтва.

Висновки. Букові й інші пралісові екосистеми мають важливе значення для обгрунтування сталого розвитку лісів на природних засадах й покращення їх багатофункціонального значення. Потрібно провести облік старовікових лісів у всіх фізикогеографічних регіонах України і вжити заходів 3 їхнього збереження. У програму навчання лісових навчальних закладів варто включити інформацію про багатогранне науково-природниче й практичне значення пралісових екосистем.

Ліси, які займають близько 30 \% суходолу нашої планети, мають важливе значення в акумуляції вуг- лецю, збереженні киснево-вуглекислотного балансу в атмосфері й подоланні небезпеки зміни клімату. Фактична площа лісів в Україні майже у два рази менша від екологічно необхідної й становить лише $17 \%$. Україна належить до найменш заліснених країн Свропи. Порівняно 3 середньоєвропейськими показниками, рівень лісозабезпечення в Україні найменший. На одного громадянина припадає лише 0,2 га лісів.

Незадовільна також вікова структура лісів. У держлісфонді стиглі й перестиглі деревостани займають $11 \%$, пристигаючі - $13 \%$, середньовікові $45 \%$, молодняки - $11 \%$. Значно гірша вікова структура лісів в інших лісокористувачів. Бажано, щоб у лісовому фонді кожна вікова група займала близько $25 \%$. У такому разі можна забезпечити рівномірний обсяг експлуатації лісів.

Для збільшення лісистості держави існують реальні можливості. У країні в різних областях числиться 403 тис. га чагарників та 205 тис. га еродованих земельних угідь, раніше вкритих лісами. Урядом України було затверджено державну цільову програму «Ліси України» на 2010-2015 рр., згідно 3 якою лісистість країни повинна збільшитись до $20 \%$. На жаль, цю програму не було виконано. Поряд 3 цим, збільшення лісистості було би вагомим внеском країни у зменшення викиду вуглекислого газу, у збільшення його депонування лісовими насадженнями, у зниження парникового ефекту для зменшення небезпеки глобальної зміни клімату. Воно матиме також економічне значення й сприятиме покращенню життєвого середовища.

\section{Бібліографічні посилання}

Cherniavsky, M. V. (2000). Primeval beech forests as model forests of the future of the Ukrainian Carpathians. Investigation of the Upper Dniester Basin Ecosystem (pp. 164-183). Lviv: UNFU (in Ukrainian).

Clements, F. E. (1936). Nature and Structure of the Climats. Yournal of Ecology, 1, 5-48.

Hamor, F. (2011). Worldwide recognition of beech primeval forests of the Carpathians: history and management. Lviv: Tysa (in Ukrainian).

Golubets, M. A. (1978). Spruce of the Ukrainian Carpathians. Kyiv: Scientific thought (in Russian).

Delehan, I. V (2005). History of forest utilization in the Transcarpathian region. Lviv: Manuscript (in Ukrainian).

Lipinsky, V. M., Dyachuk, V. D., \& Babichenko, B. M. (2003). The climate of Ukraine. Kyiv: Raevsky Publishing (in Ukrainian).

Korpel, S. (1989). Virgin forests of Slovakia. Bratislava: Veda (in Slovak).

Krynyckyy, H. T., Chernyavsky, M. V., Derbal, YuYu., Delehan, I. V., Myklush, S. I., Parpan, V.I., ... Yalovyar, P. (2014). Close-to-nature and multifunctional forest management in the Carpathian region of Ukraine and Slovakia. Uzhhorod: Kolo (in Ukrainian). 
Miklush, S. I. (2011). Beech forests of Ukraine's plains: Productivity and organization of sustainable forest management. Lviv: ZKC (in Ukrainian).

Molotkov, P. I. (1962). Beech forests and their management. Moscow: Forest industry (in Russian).

Parpan, V. I., Stojko, S. M., \& Parpan T. V. (2013). Ecological and phytocoenotic characteristics of Fageta sylvaticae of Ukraine: the possibilities of expanding their area in the context of global warming. Ukrainian Botanical Journal, 70 (3), 361-369. (in Ukrainian).

Parpan, V. I. (1994). Structure, dynamics and ecological basis for the rational use of beech forests in the Carpathian region of Ukraine (Doctoral dissertation, University of Dnipropetrovsk, IvanoFrankivsk, Ukraine)/ Retrieved from http:// dspace. nbuv.gov.ua/bitstream/handle/.../04-Parpan.pdf?...1 (in Ukrainian).

Stoyko, S. M., Zurik, Ye. I., Tretyak, P. R., Tasenkhevich L. O. et al. (1982). Morphological structure of beech primeval forests Flora and vegetation of the Carpathian reserve (pp. 178-190). Kyiv: Scientific thought (in Ukrainian).

Shparyk Yu. S. (2011). The variability and structure of beech primeval forests of the Ukrainian Carpathians. Scientific herald of the National Academy of Sciences of Ukraine: Forestry, 39, 268-277 (in Ukrainian).

Shparik, Y. S., Berkela, Y. Y., \& Pavlyuk, V. V. (2016). Structure, diversity and dynamics of primeval beech forests (Fagus sylvatica L.). of the Ukrainian Carpathians and recommendations for their implementation in sustainable forest management. Nature of the Carpathians, 1, 23-35.

Stoyko, S. (1992). Coenonic Structure of Climax and Polydominant beech Forests in Ukraine, their Ecological Characteristic and Preservation. Actas del Congereso del Haya, 11, 57-71.

Stojko, S. M. (1988). The ecological determination of the vitality of European beech (Fagus sulvatica L.) at the eastern European border of its area in the Ukrainian SSR. III IUFRO Buchensimposium, 111125. Zvolen, Slovakia (in German)

Zlatnik, A. (1938). Exploration of natural forests in Subcarpathian Russia. Brno (in Czech).

\section{Экология, ценотическая гетерогенность формации бука лесного в Украине и охрана девственных экосистем}

\author{
С.М. Стойко ${ }^{1,2}$
}

В Украине во влажном климате Карпат существуют оптимальные экологические условия для роста буковых лесов, а на Подолье - на восточноевропейской границе ареала в более сухом климате - они распространены только локально. Подана экологическая оценка физико-географических регионов Карпат, Расточья, Ополья, Подолья, в которых распространены монодоминантные и смешанные бучины, установлено их фитоценотическое разнообразие. Выяснена роль антропогенных факторов, которые являются причиной уменьшения их площади. Представлен перечень массивов естественных бучин в Карпатах, включенных МАБ ЮНЕСКО в Список объектов мирового природного наследия. Обосновано научно-естественное и экомодельное лесоводческое значение буковых и других девственных экосистем.

Отмечено, что девственные фитоценозы имеют модельное значение для обоснования системы выращивания лесов, близких по ценотической структуре к природным экосистемам и выборочному лесопользованию. Такая система дает возможность устранить противоречия между экологическими требованиями сохранения постоянства лесов и экономическими потребностями использования лесных ресурсов.

Подчеркнуто, что девственные экосистемы отмечаются биологическим разнообразием. С их локалитетов возможна миграция аборигенных видов флоры и фауны в трансформированные прилегающие леса и луга, что будет способствовать улучшению их ценотической стабильности. В девственных фитоценозах накопилась богатая информация о спонтанном развитии лесов, их естественной возрастной и ценотической структуре. Поэтому леса имеют исключительно важное значение для исследования лесообразующих процессов и функционирования экологически стабильных экосистем.

В Карпатском биосферном заповеднике, в Национальных природных парках «Зачарованный край» и «Ужанский» представлено все фитоценотическое разнообразие монодоминантных и полидоминантных буковых лесов стран Западной Европы. Они имеют важное значение для обоснования экологических основ восстановления бучин и ведения лесного хозяйства на естественной основе. Нужно

Стойко Степан Михайлович - профессор, доктор биологических наук, доктор honoris causa Зволенского технического університета (Словакия) и Львовского государственного университета безопасности жизнедеятельности (Украина), ул. Коновальца, 97, г. Львов, 79057, Украина. Тел.: +38-098-314-3591. E-mail: stepan.stojko@gmail.com

Автор этой научной статьи 14 марта 2018 года отметил свое 98-летие 
уделить должное внимание их сохранению, исследованию и внедрению результатов в улучшение экологического состояния лесов формации бучин.

На территории Угольско-Широколужанского заповедного массива Карпатсього биосферного заповедника и Ужанского НПП, среди зонально распространенных климаксовых бучин, сохранились с раннего и позднего голоцена реликтовые еловые, дубовые из дуба скального, березовые фитоценозы, имеющие значение для исследования развития растительности в послеледниковом периоде.

Буковые и другие леса экосистемы имеют исключительно важное значение для обоснования устойчивого развития лесов на естественных началах и улучшение их многофункционального значения.

Ключевые слова: охрана природы; фитоценотическое разнообразие; девственный лес; условно девственный лес; климаксовая экосистема.

\section{Ecology, coenotic heterogeneity of the forest beech formation in Ukraine and the protection of pristine ecosystems}

\author{
S. Stoyko ${ }^{1,2}$
}

In Ukraine, in the humid climate of the Carpathians, there are optimal environmental conditions for the growth of beech forests, while in the Podillia region on the Eastern European border of the range in a drier climate - they are distributed only locally. An ecological assessment is given of the physiographic regions of the Carpathians, Roztochya, Opillia, Podillia, in which monodominant and mixed beech forests are common, as well as their phytocoenotic diversity was determined. A list of natural beech forest tracts in the Carpathians is

Stepan M. Stoyko - Professor, Doctor of Biological Sciences, Doctor Honoris Causa of Zvolensky Technical University (Slovakia) and Lviv State University of Life Safety (Ukraine), 97 Konovalets st., Lviv, 79057, Ukraine. Tel: + 38-098-314-35-91. E-mail: stepan. stojko@gmail.com

The author of this scientific article celebrated his 98th anniversary on March 14, 2018 given, which is included in the UNESCO List of World Natural Heritage. Scientifically-natural and eco-model silvicultural significance of beech- and other pristine ecosystems is substantiated.

It is noted that virgin phytocoenoses have a model value for substantiating the system of forest cultivation that are close in their coenotic structure to natural ecosystems and selection system of forest use. Such a system eliminates the contradictions between the ecological requirements for maintaining forest sustainability and the economic needs of using forest resources.

It is emphasized that pristine ecosystems are marked by biological diversity. From their localities, migration of native species of flora and fauna into transformed adjacent forests and meadows is possible, which will help to improve their coenotic stability. In pristine phytocenoses a wealth of information is accumulated about the spontaneous development of forests, their natural age and coenotic structure. Therefore, forests are essential for the study of forest-forming processes and the functioning of ecologically stable ecosystems.

In the Carpathian Biosphere Reserve, in the National Natural Parks «Zacharovanyi krai» («Enchanted land») and «Uzhansky» all the phytocenotic diversity of monodominant and poly-dominant beech forests of Western Europe is presented. They are of great importance for substantiating the ecological basis for regeneration of beech forests and for forest management on a natural basis. It is necessary to pay due attention to their preservation, research and implementation of the results to improve the ecological condition of the forests of the beech formation.

On the territory of the Ugolsko-Shyrokoluzhansky protected massif of the Carpathian biosphere reserve and the Uzhansky NNP, relict spruce -, sessile oak, birch phytocoenoses, important for the study of vegetation development in the post Glacial period, have been preserved from the Early and Late Holocene.

Beech- and other forests of the ecosystems are essential to support the sustainable development of forests on a natural basis and the improvement of their multi-functional value.

Key words: nature conservation; phytocoenotic diversity; virgin forest; conditionally virgin forest; climax ecosystem. 